\title{
Pengaruh Pemberian Zat Pengatur Tumbuh Auksin Terhadap Pertumbuhan Anakan Karet Cabutan Alam (Hevea brasiliensis)
}

\author{
Nurhadiah, Nining Sri Sukasih, dan Budi Rivan Kamulyan \\ Program Studi Agroteknologi, Fakultas Pertanian, Universitas Kapuas Sintang \\ Jl. Yc. Oevang Oeray Nomor 92, Baning Kota, Sintang, 78612 \\ Korespondensi: dnurhadiah@gmail.com
}

\begin{abstract}
The development of rubber plantation in Sintang District continues to increase anually. Consequently, it is necessary to prepare a good rubber tiller. A Good rubber tiller can be obtained with the application of growth regulator when the tillers are ready to be planted. This study aimed to determine the effect of giving growth regulator Rootone-F on the growth of natural rubber saplings and to obtain a dose of Rootone-F growth regulator with the highest growth of natural rubber saplings. This study used a Randomized Block Design method, with one treatment (Rootone-F growth of regulator), consisted of 5 treatment levels: $r_{0}=$ og Rootone-F per liter of water (control), $r_{1}=1 g$ Rootone-F per liter of water, $r_{2}=2 g$ Rootone-F per liter of water, $r_{3}=3 g$ Rootone $-F$ per liter of water, $r_{4}=4 g$ Rootone- $F$ per liter of water. Each treatment was repeated 4 times. Observations were made on these variables: plant height, leaves count, and stem diameter. The results showed that the Rootone-F growth regulator had the effect on the growth of natural rubber saplings. Highest growth was achieved at the dose of $2 \mathrm{~g}$ Rootone-F per liter of water, and based on the result of that dose there was an average increase in plant height $(8.88 \mathrm{~cm})$ and an average number of leaves (4.78 leaves).
\end{abstract}

Keywords: growth regulator, natural rubber saplings, plant height.

\section{PENDAHULUAN}

Karet berasal dari benua Amerika dan saat ini menyebar luas ke seluruh dunia. Karet dikenal di Indonesia sejak masa kolonial Belanda, dan merupakan salah satu komoditas perkebunan yang memberikan sumbangan besar bagi perekonomian Indonesia. Karet (Hevea brasiliensis) merupakan komoditas perkebunan yang sangat penting peranannya di Indonesia. Selain sebagai sumber lapangan kerja bagi 1,4 juta tenaga kerja, komoditas ini memberikan kontribusi yang signifikan sebagai salah satu sumber devisa nonmigas, pemasok bahan baku karet, dan berperan penting dalam mendorong sentra-sentra ekonomi baru di wilayah-wilayah pengembangan karet (Tim Karya Tani Mandiri, 2012).

Daerah sentra produksi penghasil karet terbesar di Indonesia yaitu: Sumatera Selatan (860 ribu hektar), Sumatera Utara (400 ribu hektar), Jambi (390 ribu hektar), Kalimantan Barat (385 ribu hektar), dan Riau (330 ribu hektar) (Badan Pusat Statistik, 2019). Luas total perkebunan karet di Indonesia telah mencapai 3.325 .894 ha. Berdasarkan pengusahaannya, $88,86 \%$ merupakan kebun milik rakyat, 6,61\% milik swasta dan 4,53\% milik negara (Badan Pusat Statistik, 2019).

Menurut BPS Provinsi Kalimantan Barat (2017), sebanyak 1.112.674 jiwa penduduk Provinsi Kalimantan Barat mata pencahariannya sebagai petani, termasuk didalamnya petani karet yang mengelola 594.154 ha kebun karet. Perkembangan luas kebun karet perlu diimbangi dengan penyediaan bibit dalam jumlah yang cukup, terutama di Kabupaten Sintang. Berdasarkan BPS Kabupaten Sintang (2017) luas kebun karet di Kabupaten Sintang dapat dilihat pada Tabel 1.

Tabel 1 Luas Kebun Karet di Kabupaten Sintang

\begin{tabular}{cc}
\hline Tahun & Luasan (hektar) \\
\hline 2012 & $84.150,0$ \\
2013 & $84.930,0$ \\
2014 & $86.169,0$ \\
2015 & $90.311,0$ \\
2016 & $93.112,5$
\end{tabular}

Sumber: Badan Pusat Statistik Kabupaten Sintang (2017)

Salah satu cara dalam perbanyakan tanaman karet adalah dengan bibit cabutan 
alam (Soetarno dkk., 2000). Bibit cabutan adalah anakan pohon yang tumbuh dan dimanfaatkan sebagai bibit dan cara pengumpulannya dengan cabutan. Anakan yang tumbuh berlimpah umumnya berasal dari pohon induk didekatnya. Anakan cabutan ini memiliki daya adaptasi yang lebih baik, lebih tahan penyakit dan berumur lebih panjang (Setiawan dan Agus, 2005). Permasalah pembibitan dari bibit yang pengambilannya dengan proses dicabut diantaranya pertumbuhannya lama karena perakarannya rusak akibat proses pencabutan.

Salah satu cara untuk mempercepat pertumbuhan pada bibit cabutan perlu diberikan Zat Pengatur Tumbuh (ZPT) jenis auksin yang dapat merangsang perakaran. Payung dan Susilawati (2014) menjelaskan bahwa zat pengatur tumbuh dari jenis auksin dapat digunakan untuk membantu mempercepat keluarnya akar pada stek. Salah satu merk dagang ZPT-auksin adalah Rootone $\mathrm{F}$, yang mengandung beberapa bahan aktif senyawa auksin seperti NAA dan IBA. Aplikasi ZPTauksin harus diberikan dalam konsentrasi yang sesuai agar didapatkan hasil yang optimal. Konsentrasi yang terlalu rendah maupun terlalu tinggi tidak bagus untuk pertumbuhan. Menurut Rochiman dan Harjadi (1997), zat pengatur tumbuh tidak efektif jika konsentrasi terlalu rendah (di bawah tingkat optimum) dan atau terlalu tinggi (di atas tingkat optimum).

Upaya peningkatan penyedian bibit karet dengan cara cabutan ini perlu dilakukan penelitian dengan tujuan untuk mengetahui pengaruh pemberian zat pengatur tumbuh Rootone-F terhadap pertumbuhan anakan karet cabutan alam, serta untuk mengetahui dosis zat pengatur tumbuh Rootone-F yang memberikan hasil terbaik terhadap pertumbuhan anakan karet cabutan alam.

\section{METODE PENELITIAN}

Penelitian dilaksanakan di kebun percobaan Fakultas Pertanian Universitas Kapuas Sintang. Percobaan dilakukan dengan menggunakan polibag. Penelitian dilaksanakan selama 4 bulan dimulai dari bulan April sampai Juli tahun 2017.
Penelitian ini menggunakan metode percobaan lapangan, dilaksanakan dengan rancangan acak kelompok (RAK) terdiri atas 5 taraf perlakuan, yaitu:

$$
\begin{aligned}
& r_{0}: \text { tanpa pemberian Rootone-F } \\
& r_{1}: 1,0 \text { g Rootone-F per liter air } \\
& r_{2}: 2,0 \text { g Rootone-F per liter air } \\
& r_{3}: 3,0 \text { g Rootone-F per liter air } \\
& r_{4}: 4,0 \text { g Rootone-F per liter air. }
\end{aligned}
$$

Setiap satuan percobaan terdiri atas 4 tanaman dan 5 ulangan. Satuan pengamatan terdiri dari seluruh tanaman dalam petak percobaan. Jumlah seluruh satuan pengamatan adalah 100 tanaman.

Alat yang digunakan dalam penelitian ini diantaranya: ember, meteran, timbangan, gunting, jangka sorong, cangkul, gembor, kantong plastik kecil, botol 1,5 L, kamera, kalkulator dan alat tulis. Sedangkan bahan yang digunakan adalah: anakan karet, ZPT RootoneF, polybag, tanah, kompos, dan paranet.

Anakan karet yang digunakan dalam penelitian ini adalah anakan karet cabutan alam dengan kisaran tinggi 45-70 cm. Anakan karet tersebut dikelompokan dengan ukuran yang relatif sama. Sebelum diberi perlakuan, daun bawaan pada anakan dipotong untuk mengurangi transpirasi pada anakan karet.

Pelaksanaan penelitian meliputi: persiapan media tanam, persiapan anakan karet, pengukuran awal bibit, aplikasi zat perangsang tumbuh Rootone-F, penanaman, pemeliharaan dan pengumpulan data. Persiapan media tanam dilakukan dengan mencampur topsoil tanah podsolik merah kuning dan kompos dengan perbandingan 2:1. Selanjutnya campuran topsoil dan kompos tersebut dimasukan dalam polybag sebanyak 100 polybag dengan berat masing-masing polybag $8 \mathrm{~kg}$.

Pemberian perlakuan dilakukan dengan merendam anakan karet dalam larutan Rootone-F sesuai perlakuan selama 60 menit. Setelah melakukan perendaman dalam larutan Rootone-F, anakan karet ditanam dalam polybag. Tempat percobaan diberi naungan untuk mengurangi radiasi matahari yang terlalu 
tinggi. Selama percobaan dilakukan pemeliraan seperti penyiraman dengan rutin, dan penyiangan gulma.

Pengamatan dilakukan terhadap pengukuran tinggi, jumlah daun dan diameter batang anakan karet. Pengukuran tinggi tanaman, jumlah daun dan diameter batang anakan karet dilakukan pada umur anakan karet 90 hari setelah tanam. Pengukuran ini dilakukan untuk mendapatkan data pertambahan tinggi, jumlah daun dan pertambahan diameter batang.

Data yang diperoleh dari hasil penelitian dianalisis statistic dengan menggunakan analisis sidik ragam. Jika hasil analisis sidik ragam menunjukan ada pengaruh perlakuan Rootone-F, maka dilanjutkan dengan uji beda nyata jujur untuk mengetahui perbedaan pengaruh antar taraf Rootone-F yang diberikan.

\section{HASIL DAN PEMBAHASAN}

\subsection{Pertambahan Tinggi Tanaman}

Data rerata pertambahan tinggi tanaman diperoleh dengan mengukur tinggi tanaman di akhir penelitian dikurangi pengukuran awal. Data rerata ini dianalisis dengan menggunakan analisis sidik ragam yang hasilnya disajikan pada Tabel 2.

Tabel 2 Hasil analisis sidik ragam untuk peubah pertambahan tinggi tanaman

\begin{tabular}{ccccccc}
\hline \multirow{2}{*}{$\begin{array}{c}\text { Sumber } \\
\text { Keragaman }\end{array}$} & $\begin{array}{c}\text { Derajat } \\
\text { Bebas }\end{array}$ & $\begin{array}{c}\text { Jumlah } \\
\text { Kuadrat }\end{array}$ & $\begin{array}{c}\text { Kuadrat } \\
\text { Tengah }\end{array}$ & F-hitung & \multicolumn{2}{c}{ F Tabel } \\
\cline { 5 - 7 } Kelompok & 4 & 14,65 & 3,66 & $2,46^{\text {ns }}$ & 3,05 & 0,01 \\
Perlakuan & 4 & 30,44 & 7,62 & $5,12^{* *}$ & 3,01 & 4,78 \\
Galat & 16 & 23,78 & 23,78 & & & \\
Total & 24 & 68,88 & & KK $=17,68 \%$ & \\
\hline Keterangan: & ** & Berpengaruh sangat nyata pada selang kepercayaan 99\%
\end{tabular}

Hasil analisis sidik ragam (Tabel 2) menunjukan bahwa ZPT Rootone-F sangat berpengaruh nyata terhadap pertambahan tinggi tanaman. Untuk mengetahui perbedaan pengaruh antar konsentrasi ZPT Rootone-F dilanjutkan dengan uji BNJ pada taraf nyata 5 dan $1 \%$, yang hasilnya ditampilkan pada Tabel 3.

Tabel 3 Pertambahan Tinggi Anakan Karet Cabutan Alam Akibat Perlakuan ZPT Rootone-F

\begin{tabular}{cc}
\hline Perlakuan & $\begin{array}{c}\text { Rerata Pertambahan } \\
\text { Tinggi }(\mathrm{cm})\end{array}$ \\
\hline $\mathrm{r}_{0}$ & $5,55 \mathrm{a}$ \\
$\mathrm{r}_{1}$ & $6,34 \mathrm{a}$ \\
$\mathrm{r}_{2}$ & $8,88 \mathrm{~b}$ \\
$\mathrm{r}_{3}$ & $7,00 \mathrm{a}$ \\
$\mathrm{r}_{4}$ & $6,68 \mathrm{a}$ \\
\hline
\end{tabular}

$\mathrm{BNJ}_{0,05}=2,36$

Keterangan: Angka yang diikuti oleh huruf yang sama menunjukkan tidak berbeda nyata pada uji BNJ 5\%
Hasil uji BNJ (Tabel 3) menunjukan bahwa rerata pertambahan tinggi anakan karet tanpa perlakuan ZPT Rootone-F ( $\mathrm{r}_{\mathrm{o}}$ ), lebih rendah dibandingkan dengan anakan karet yang diberi perlakuan ZPT Rootone-F. Anakan karet yang diberi perlakuan ZPT Rootone-F menunjukan adanya aktivitas hormon yang ditambahkan melalui akar sehingga memacu pertumbuhan akar. Pertumbuhan akar yang baik akan mempengaruhi pertumbuhan pucuk, termasuk pertambahan tinggi tanaman dan jumlah daun.

Menurut Lidar (2008) pemberian ZPT secara umum dapat meningkatkan pertumbuhan bibit karet stump mata tidur, sedangkan bibit karet stump mata tidur yang tidak diberi ZPT pertumbuhannya paling rendah. Pertumbuhan bibit karet yang rendah diduga karena bibit tidak terpacu pertumbuhannya dibandingkan dengan bibit karet stump mata tidur yang diberi perlakuan ZPT yang pertumbuhannya menjadi terpacu. Rohma dan Jazilah (2019) menambahkan bahwa konsentrasi Rootone F berbeda sangat nyata terhadap 
kecepatan tumbuh tunas, panjang tunas, jumlah daun, dan jumlah akar.

Pemberian ZPT Rootone-F sebanyak 1 g per liter air $\left(\mathrm{r}_{1}\right), 3 \mathrm{~g}$ per liter air dan $4 \mathrm{~g}$ per liter air tidak berbeda nyata dengan tanpa pemberian ZPT Rootone-F $\left(\mathrm{r}_{0}\right)$. Hal ini dijelaskan oleh Sudomo dkk. (2013) bahwa hormon tumbuh dalam jumlah tertentu (optimal) akan aktif mengatur reaksi-reaksi metabolik penting dan salah satunya untuk memacu pertumbuhan akar. Pertumbuhan akar yang cepat akan meningkatkan pertumbuhan tunas. Dalam penelitian ini, pemberian ZPT Rootone-F sebanyak $2 \mathrm{~g}$ per liter air diduga merupakan pemberian yang optimal pada anakan karet cabutan alam, dimana rerata pertambahan tinggi tanaman tertinggi $8,88 \mathrm{~cm}$.

\subsection{Jumlah Daun}

Data jumlah daun diperoleh dengan menghitung daun yang tumbuh sempurna setelah aplikasi ZPT Rootone-F. Data rerata jumlah daun dianalisis dengan analisis sidik ragam hasilnya disajikan pada Tabel 4 .

Tabel 4 Hasil analisis sidik ragam untuk peubah jumlah daun

\begin{tabular}{ccccccc}
\hline Sumber & Derajat & Jumlah & Kuadrat & \multirow{2}{*}{ F-hitung } & \multicolumn{2}{c}{ F -tabel } \\
\cline { 6 - 7 } Keragaman & Bebas & Kuadrat & Tengah & 2-05 & 0,01 \\
\hline Kelompok & 4 & 3,71 & 0,93 & $2,75 \mathrm{~ns}$ & 3,01 & 4,78 \\
Perlakuan & 4 & 6,86 & 1,72 & $4,76^{* *}$ & 3,01 & 4,78 \\
Galat & 16 & 5,77 & 0,36 & & & \\
\hline Total & 24 & 16,33 & & KK $=15,67 \%$ & \\
\hline
\end{tabular}

Keterangan: ${ }^{* *}=$ Berpengaruh sangat nyata pada selang kepercayaan $99 \%$

Hasil analisis sidik ragam (Tabel 4) menunjukan bahwa ZPT Rootone-F sangat berpengaruh nyata terhadap jumlah daun. Untuk mengetahui perbedaan pengaruh antar konsentrasi ZPT Rootone-F dilanjutkan dengan uji BNJ pada taraf nyata 5 dan $1 \%$, yang hasilnya ditampilkan pada Tabel 5.

Tabel 5 Jumlah Daun Anakan Karet Cabutan Alam Akibat Perlakuan ZPT Rootone-F

\begin{tabular}{cc}
\hline Perlakuan & Rerata jumlah daun \\
\hline $\mathrm{r}_{0}$ & $3,25 \mathrm{a}$ \\
$\mathrm{r}_{1}$ & $3,57 \mathrm{a}$ \\
$\mathrm{r}_{2}$ & $4,78 \mathrm{~b}$ \\
$\mathrm{r}_{3}$ & $3,93 \mathrm{a}$ \\
$\mathrm{r}_{4}$ & $3,62 \mathrm{a}$ \\
\hline
\end{tabular}

$\mathrm{BNJ}_{0,05}=1,16$

Keterangan: Angka yang diikuti oleh huruf yang sama menunjukkan tidak berbeda nyata pada uji BNJ 5\%

Hasil uji BNJ (Tabel 5) menunjukan bahwa perlakuan $r_{0}, r_{1}, r_{4}$, dan $r_{3}$ tidak berbeda nyata, sedangkan $r_{2}$ berbeda sangat nyata dengan perlakuan yang lainnya, dapat dilihat pula perlakuan $r_{2}$ dengan pemberian ZPT Rootone- $F$ sebanyak 2 g per liter air memberikan rerata jumlah daun tertinggi $(4,78$ helai).

Menurut Campbell et al. (1999) meristem apikal yang terdapat di zona pembelahan menghasilkan sel-sel meristem primer yang bersifat meristematik, sehingga mendorong pembelahan sel-sel di ujung-ujung akar dan tunas. Meristem akan mendukung partumbuhan secara terus-menerus yang disebabkan oleh pembelahan sel dan pemanjangan sel dalam ruas tersebut sehingga mengarah pada pemanjangan tunas dan pembentukan daun.

Anakan karet yang tidak diberi perlakuan ZPT Rootone-F ( $\mathrm{r}_{\text {o) }}$ memberikan rerata jumlah daun paling rendah, dibandingkan dengan anakan karet yang diberi perlakuan. Pertumbuhan yang terjadi pada anakan karet $r_{o}$ karena anakan karet cabutan alam ini masih muda, dan dipacu oleh hormon alami yang terdapat pada anakan karet itu sendiri. Istomo dkk (2014) menjelaskan bahwa bibit yang masih muda (semai juvenile) memiliki kemampuan untuk melakukan perpanjangan sel yang pesat (fase juvenile). Selanjutnya Putri dan Danu (2014) menambahkan bahwa auksin alami yang 
dihasilkan oleh tanaman berperan untuk mengubah cadangan karbohidrat menjadi gula larut yang sangat diperlukan untuk pembelahan sel serta meningkatkan mobilisasi gula dari daun ke pangkal stek untuk pembentukan primordia akar menjadi akar. Pertumbuhan akar akan mempengaruhi pertumbuhan pucuk tanaman.

Jumlah daun yang terbentuk pada anakan karet tidak terlepas dari proses fisiologis yang dipacu oleh hormon. ZPT Rootone-F yang ditambahkan pada anakan karet $\left(\mathrm{r}_{1}, \mathrm{r}_{2}, \mathrm{r}_{3}\right.$ dan $r_{4}$ ), memberikan tambahan hormon dalam memacu proses fisiologis yang terjadi, sehingga diduga rerata jumlah daun menjadi lebih tinggi pada anakan karet yang diberi perlakuan ZPT Rootone-F. Lidar (2008) menjelaskan bahwa pemberian zat pengatur tumbuh adalah sebagai perangsang yang mempengaruhi kerja enzim dan berperan sebagai katalisator yang dapat merangsang pembelahan dan pengembangan sel serta jaringan tanaman.
Perlakuan ZPT Rootone-F memberikan pengaruh yang berbeda terhadap anakan karet cabutan alam. Tabel 5 menunjukan bahwa pemberian ZPT Rootone-F sebanyak 2 g per liter air memberikan rerata jumlah daun lebih tinggi dibandingkan dengan pemberian ZPT Rootone-F sebanyak $3 \mathrm{~g}$ per liter air dan $4 \mathrm{~g}$ per liter air. Hal ini dijelaskan oleh Adinugraha dkk. (2007) bahwa makin tinggi konsentrasi zat pengatur tumbuh yang digunakan, menghasilkan persentase bertunas dan berakar yang makin rendah.

\subsection{Pertambahan Diameter Batang}

Data pertambahan diameter batang diperoleh dengan mengukur diameter batang di akhir penelitian dikurangi pengukuran diameter batang awal. Hasil pengukuran ini, diperoleh data rerata pertambahan diameter batang yang selanjutnya dianalisis dengan menggunakan analisis sidik ragam yang hasilnya disajikan pada Tabel 6 .

Tabel 6 Hasil analisis sidik ragam untuk peubah pertambahan diameter batang

\begin{tabular}{ccccccc}
\hline Sumber & Derajat & Jumlah & Kuadrat & \multirow{2}{*}{ F-hitung } & \multicolumn{2}{c}{ F-tabel } \\
\cline { 6 - 7 } Keragaman & Bebas & Kuadrat & Tengah & & 0,05 & 0,01 \\
\hline Kelompok & 4 & 0,06 & 0,02 & $0,42^{\text {ns }}$ & 3,01 & 4,78 \\
Perlakuan & 4 & 0,13 & 0,03 & $0,8^{\text {ns }}$ & 3,01 & 4,78 \\
Galat & 16 & 0,63 & 0,04 & & & \\
\hline Total & 24 & 0,83 & \multicolumn{3}{c}{ KK $=34,84 \%$} \\
\hline
\end{tabular}

Keterangan: ns = Tidak berpengaruh nyata pada selang kepercayaan 95\%

Hasil analisis ragam (Tabel 6) menunjukan bahwa ZPT Rootone-F tidak berpengaruh terhadap pertambahan diameter batang bibit karet cabutan alam. Hal ini diduga karena respon tanaman yang berumur 3 (tiga) bulan belum menunjukan respon yang berarti terhadap pertumbuhan bibit. Selain itu juga daya dukung lingkungan yang kurang memadai sehingga zat pengatur tumbuh yang diberikan tidak dapat memicu pertumbuhan anakan karet secara optimal. Hal ini sejalan dengan pendapat Tahir (1991) yang menyatakan semua unsur yang dibutuhkan tanaman perlu berada dalam suatu media di sekitar tanaman dan unsurunsur ini dalam bentuk yang dapat diserap oleh tanaman.
Selain umur bibit, naungan yang diberikan pada bibit karet cabutan alam ini juga menjadi salah satu penyebab tidak berpengaruhnya perlakuan ZPT Rootone-F terhadap pertambahan diameter batang. Afandi dkk. (2013) mengemukakan bahwa pada kondisi ternaungi intensitas cahaya yang dapat diterima tanaman akan sedikit sehingga terjadi peningkatan aktifitas auksin dan akibatnya sel-sel tumbuh memanjang. Ningrum, dkk (2014) menjelaskan bahwa tanaman yang ditanam tanpa naungan memberikan pengaruh nyata tertinggi pada diameter batang. Hal tersebut dikarenakan serapan cahaya matahari pada perlakuan tanpa naungan lebih besar dibandingkan dengan perlakuan menggunakan naungan. Marjenah 
(2001) menyatakan pertumbuhan diameter batang lebih cepat pada tempat terbuka daripada tempat ternaung sehingga tanaman yang ditanam di tempat terbuka cenderung pendek dan kekar.

\section{KESIMPULAN}

Zat pengatur tumbuh Rootone-F berpengaruh terhadap pertumbuhan anakan karet cabutan alam, yang ditunjukan oleh peubah pertambahan tinggi tanaman dan jumlah daun. Pertumbuhan tertinggi akibat pemberian ZPT Rooton-F dicapai pada dosis 2 gram dimana dengan rataan pertambahan tinggi tanaman dan jumlah daun tertinggi. Pada dosis tersebut menghasilkan rerata pertambahan tinggi tanaman $(8,88 \mathrm{~cm})$ dan rerata jumlah daun $(4,78$ helai).

\section{DAFTAR PUSTAKA}

Adinugraha, H. A., S. Pudjiono dan D. Yudistiro. 2007. Pertumbuhan stek pucuk dari tunas hasil pemangkasan semai jenis Euchalyptus pellita F. Muell di persemaian. Jurnal Pemuliaan Tanaman Hutan. 1(1): 43 - 49.

Afandi, M., L. Mawarni, dan Syukri. 2013. Respon pertumbuhan dan produksi empat varietas kedelai (Glycine max L.) terhadap tingkat naungan. Jurnal Online Agroekoteknologi. 1 (2): 214226.

BPS Kalimantan Barat. 2017. Kalimantan Barat Dalam Angka. Pontianak: Badan Pusat Statistik Kalimantan Barat.

BPS Kabupaten Sintang. 2017. Kabupaten Sintang Dalam Angka. Sintang: Badan Pusat Statistik Kabupaten Sintang.

Badan Pusat Statistik. 2019. Statistik Karet Indonesia. Badan Pusat Statistik. Jakarta.

Campbell, N.A., J. B. Reece and L.E. Mitchell. 1999. Biologi. Jakarta: Erlangga.
Istomo, A. Subiakto dan S. Rahmadianto. 2014. Pengaruh asal bahan dan media stek terhadap keberhasilan stek pucuk tembesu Fagraea fragrans (Roxb.) Berita Biologi. 13(3): 275 - 281.

Putri, K. P. dan Danu. 2014. Pengaruh umur bahan stek dan zat pengatur tumbuh terhadap keberhasilan stek Kemenyan (Styrax benzoin Dryand). Jurnal Penelitian Hutan Tanaman. 11(3): 144-145.

Lidar, S. 2008. Pengaruh zat pengatur tumbuh (ZPT) terhadap pertumbuhan bibit karet (Hevea brasiliensis) stump mata tidur. Jurnal Ilmiah Pertanian. 4(2): $47-54$.

Marjenah. 2001. Pengaruh perbedaan naungan di persemaian terhadap pertumbuhan dan respon morfologi dua jenis semai meranti. Jurnal Ilmiah Kehutanan Rimba Kalimantan. 6 (2): 14-19.

Ningrum M. K., T. Sumarni, dan Sudiarso. 2014. Pengaruh naungan pada teknik pembibitan bud chip tiga varietas tebu (Saccharum officinarum L.). Jurnal Produksi Tanaman. 2(3): 260267.

Payung, D dan Susilawati. 2014. Pengaruh zat pengatur tumbuh Rootone-F dan sumber bahan stek terhadap pertumbuhan stek tembesu (Fagraea fragrans) di PT. Jorong Barutama greston Kalimantan Selatan. Enviro Scienteae. 10 (3): 140-149.

Rochiman, K dan Harjadi, S. S. 1997. Pembiakan Vegetatif. Departemen Agronomi, Institut Pertanian Bogor. Bogor.

Rohma, S. I. dan Jazilah, S. 2019. Pengaruh konsentrasi dan lama perendaman Rootone $\mathrm{F}$ terhadap pertumbuhan stek mawar (Rosa sp.). Biofarm. 15(1): $20-24$.

Setiawan D. H., dan Agus, A. 2005. Petunjuk Lengkap Budidaya Karet. Agromedia Pustaka. Jakarta. 
Soetarno, H, N. Hidayati, Roemantyo, Y. S. Purba, N. W. Utami, dan N. Suwarya. 2000 Teknik Produksi Bibit Pohon Hutan. Yayasan PROSEA. Bogor.

Sudomo, A. Rohandi, dan N. Mindawati, N. 2013. Penggunaan zat pengatur tumbuh rootone-f pada stek pucuk manglid (Manglietia glauca bi). Jurnal Penelitian Hutan Tanaman. 10(2): 57-63.

Tahir, S. M. 1991. Tumpang Gilir. Jakarta: CV. Yasaguna.

Tim Karya Tani Mandiri, 2012. Pedoman Bertanam Karet. Nuansa Aulia. Bandung. 